\section{Evaluasi Kandungan Lemak Kasar dan BETN Silase Daun Lamtoro pada Level yang Berbeda Sebagai Bahan Pakan Utama Pakan Komplit}

\author{
Juwandi \\ Munir \\ Fitriani
}

\begin{abstract}
Abstrak. Tujuan penelitian ini adalah untuk mengetahui kandungan lemak kasar dan BETN silase kombinasi bahan jerami padi dan daun lamtoro pada level yang berbeda sebagai bahan pakan utama pakan komplit. Penelitian ini menggunakan Rancangan Acak Lengkap (RAL) dengan 4 taraf perlakuan dan 3 ulangan yaitu Kontrol $=100 \%$ jerami padi (Kontrol), 40\% $=60 \%$ jerami padi + $40 \%$ daun lamtoro, $30 \%=70 \%$ jerami padi $+30 \%$ daun lamtoro, $20 \%=80 \%$ jerami padi $+20 \%$ daun lamtoro. Hasil penelitian menunjukkan bahwa dengan pencampuran bahan jerami padi dan daun lamtoro sebagai pakan komplit berpengaruh sangat nyata terhadap kandungan lemak kasar dan berpengaruh nyata terhadap kandungan BETN. Berdasarkan hasil dan pembahasan penelitian, maka dapat disimpulkan bahwa pakan dengan kombinasi jerami padi dan daun lamtoro mempengaruhi kandungan lemak kasar dan BETN. Dimana perlakuan $40 \%$ dengan kombinasi bahan jerami padi $60 \%$ dan daun lamtoro $40 \%$ menunjukkan hasil yang terbaik untuk kandungan lemak dan BETN.

Kata Kunci: lemak, BETN, jerami padi, daun lamtor; dan silase.
\end{abstract}

\section{Pendahuluan}

Pakan memiliki peranan penting bagi ternak, baik untuk pertumbuhan ternak muda maupun untuk mempertahankan hidup dan menghasilkan produk berupa susu, anak, daging serta tenaga bagi ternak dewasa. Fungsi lain dari pakan adalah untuk memelihara daya tahan tubuh dan kesehatan. Agar pertumbuhan ternak sesuai yang diharapkan, jenis pakan yang diberikan pada ternak harus bernilai gizi baik dan dalam jumlah yang cukup. Setiap bahan pakan, baik yang sengaja kita berikan kepada ternak maupun yang diperolehnya sendiri, mengandung unsur-unsur nutrisi yang konsentrasinya sangat bervariasi tergantung pada jenisnya dan keadaan bahan pakan tersebut yang secara kompak akan mempengaruhi tekstur dan strukturnya. Unsur nutrisi yang terkandung di dalam bahan pakan secara umum terdiri atas air, mineral, protein, lemak, karbohidrat dan vitamin. Setelah dikonsumsi oleh ternak, setiap unsur nutrisi berperan sesuai dengan fungsinya terhadap tubuh ternak untuk mempertahankan hidup dan berproduksi secara normal.

Ketersediaan pakan masih menjadi kendala pengembangan ternak ruminansia di Indonesia. Kendala yang belakangan ini dihadapi dalam menyediaan pakan hijauan adalah keterbatasan lahan tanam hijauan. Oleh karena itu, dibutuhkan sumber hijauan alternatif yang dapat dimanfaatkan pada musim kemarau untuk memenuhi Kebutuhan pakan ternak ruminansia yang memiliki kualitas dan kandungan nutrien yang tinggi. Salah satu upaya yang dilakukan adalah pembuatan pengawetan pakan dengan cara silase. Silase adalah pakan yang telah diawetkan yang di

\section{BIONATURE}

p-ISSN 1411 - 4720

e-ISSN 2654 - 5160

Abstract. The purpose of this study was to determine the crude fat content and BETN silage combination of rice straw and lamtoro leaves at different levels as the main feed ingredients for complete feed. This study used a completely randomized design (CRD) with 4 treatment levels and 3 replications namely contro $=100 \%$ rice straw (control), $40 \%=60 \%$ rice straw $+40 \%$ lamtoro leaf, $30 \%=70 \%$ rice straw +

$30 \%$ lamtoro leaves, $20 \%=80 \%$ rice straw $+20 \%$ lamtoro leaves. The results showed that the mixing of rice straw and lamtoro leaves as a complete feed had a very significant effect on crude fat content and had a significant effect on BETN content. Based on the results and discussion of the study, it can be concluded that feed with a combination of rice straw and lamtoro leaves affects the crude fat content and BETN. Where the treatment of $40 \%$ with a combination

of $60 \%$ rice straw material and $40 \%$ leucaena leaves showed the best results for fat content and BETN.

Keywords: fat, BETN, rice straw, lamtoro leaf, and silage.

Juwandi

Universitas Muhammadiyah Parepare Indonesia

Munir

Universitas Muhammadiyah Parepare Indonesia

Fitriani

Universitas Muhammadiyah Parepare Indonesia 
proses dari bahan baku yang berupa tanaman hijauan, limbah industri, pertanian, serta bahan pakan alami lainnya, dengan kandungan air pada tingkat tertentu kemudian dimasukkan dalam sebuah tempat yang tertutup rapat kedap udara, yang bisa di sebut dengan silo, selama sekitar tiga minggu. Didalam silo tersebut akan terjadi beberapa tahap proses anaerob (proses tanpa udara/oksigen), dimana "bakteri asam laktat akan mengkonsumsi zat gula yang terdapat pada bahan baku, sehingga terjadilah proses fermentasi. Silase yang terbentuk karena proses fermentasi ini dapat disimpan untuk jangka waktu yang lama tanpa mengurangi kandungan nutrisi dan bahan bakunya.

Jerami padi merupakan salah satu limbah pertanian yang potensial untuk dimanfaatkan sebagai pakan ternak ruminansia pada saat persediaan rumput berkurang. Hambatan dalam pemanfaatannya adalah adanya faktor pembatas dengan nilai nutrisi yang rendah yaitu kandungan lemak kasar rendah, serat kasar tinggi serta kecernaannya hanya 37\%, sehingga dalam pemanfaatannya sebagai pakan ternak masih terbatas (Gazali, 2014).

Salah satu langkah untuk meningkatkan jerami padi sebagai pakan ternak perlu dilakukan penambahan bahan yang memiliki kualitas nutrisi yang baik. Untuk mencukupi kebutuhan nutrisi tersebut maka dicarikan bahan baku pakan ternak yang mudah didapat, ketersediaannya melimpah, dan memiliki kandungan nutrisi tinggi seperti daun lamtoro (Indayani, 2012).

Lamtoro merupakan salah satu tanaman leguminoceae yang mempunyai sistem perakaran yang kuat dan dalam, tahan terhadap kekeringan, tetap hijau dan bertunas selama musim kering, sehingga sangat cocok sebagai sumber hijauan pakan ternak ruminansia seperti kerbau, sapi, kambing dan domba. Produksi hijauannya cukup tinggi bervariasi sesuai dengan tingkat kesuburan tanah, jarak tanam dan curah hujan. Daun dan batang muda sangat disukai ternak ruminansia (Hartanto, 2008). Tanaman lamtoro diketahui banyak mengandung protein dan sangat baik digunakan sebagai pakan ternak. Tanaman tersebut mempunyai palatabilitas yang tinggi, pertumbuhannya cepat dan mudah tumbuh serta merupakan tumbuhan yang hidup subur pada daerah tropis. Biasanya peternak menggunakan sistem cut and carry sebagai bahan pakan ternak ruminansia. Kandungan nutrien lamtoro adalah protein kasar (PK) 23,7\%, serat kasar (SK) 18\% dan lemak kasar (LK) 5,8\% (Hartadi dkk., 2005).

Produktivitas ternak yang rendah pada peternakan disebabkan ternak hanya diberi pakan rumput yang kandungan nutrisinya rendah. Produktivitas ternak akan meningkat bila kebutuhan gizinya terpenuhi antara lain dengan pemberian pakan tambahan yang berkualitas. Menurut Indayani (2012) lamtoro sebagai pakan hijauan yang berkualitas belum dimanfaatkan secara optimal dan belum banyak dikomersilkan. Lamtoro mengandung protein, mineral, dan asam amino yang seimbang, serta mempunyai serat kasar yang relatif sedikit (Prabowo, 2006).

Sehubungan dengan hal tersebut maka akan dilakukan penelitian mengenai evaluasi kandungan lemak kasar dan BETN silase kombinasi jerami padi dan daun lamtoro pada level yang berbeda sebagai bahan pakan utama pakan komplit.

\section{Metode Penelitian}

\section{Waktu dan Tempat Penelitian}

Penelitian ini dilaksanakan pada bulan Juli sampai Agustus 2018. Pembuatan silase kombinasi jerami padi dan daun lamtoro di lakukan di Laboratorium Fakultas Pertanian, Peternakan dan Perikanan Universitas Muhammadiyah Parepare dan dilanjutkan dengan analisa proksimat, di Laboratorium Kimia Makanan Ternak, Fakultas Peternakan Universitas Hasanuddin Makassar. 


\section{Desain Penelitian}

Metode Penelitian dirancang menurut Rancangan Acak Lengkap (RAL) menurut Hading (2014). Terdiri dari 4 perlakuan dan setiap perlakuan diulang sebanyak 3 kali. Susunan perlakuan sebagai berikut:
Kontrol : 100\% Jerami Padi + 0\% Daun Lamtoro
40\% $\quad: 60 \%$ jerami Padi $+40 \%$ Daun Lamtoro
$30 \% \quad: 70 \%$ Jerami Padi $+30 \%$ Daun Lamtoro
20\% : : $80 \%$ Jerami Padi $+20 \%$ Daun Lamtoro

\section{Alat dan Bahan}

Alat-alat yang digunakan adalah alat pencacah jerami, timbangan, alat pres (katrol hidrolitik), plastik untuk silo, terpal, label, spidol, dan alat analisis proksimat untuk mengetahui kandungan bahan pakan yang terdiri dari air, abu, protein kasar, lemak, BETN, dan serat kasar. Bahan yang digunakan pada penelitian ini yaitu jerami padi, daun lamtoro, dedak, molases dan air. serta bahan kimia untuk analisa proksimat.

\section{Prosedur Kerja}

Penelitian ini diawali dengan pengambilan bahan jerami padi dan daun lamtoro kemudian dilayukan untuk menurunkan kadar air. Daun lamtoro yang digunakan diambil dari kebun rumput di Desa Uluale Kabupaten Sidrap. Selanjutnya pembuatan silase pakan komplit dilakukan dengan mencacah jerami padi sepanjang $\pm 3 \mathrm{~cm}$. Jerami padi, daun lamtoro, dedak, molases dan air dicampur hingga homogen. Lalu dimasukkan kedalam silo atau plastik kedap udara. Pakan komplit yang telah dicampur dan ditutup secara rapat hingga tidak ada udara yang bebas masuk dan disimpan ditempat teduh. Bahan disimpan dalam keadaan an aerob selama 21 hari (Indah, 2016).

Setelah 21 hari silase dibuka dari plastik silo, selanjutnya pengambilan sampel pada semua unit percobaan masing-masing 100-gram kemudian di ovenkan dan dihaluskan. Langkah selanjutnya yaitu analisis proksimat untuk mengetahui kandungan Nutrisi (Indah, 2016).

\section{Parameteryang Diukur}

Parameter yang diukur dalam penelitian ini adalah kandungan lemak kasar dan bahan ekstrak tanpa nitrogen.

\section{Analisis Data}

Data yang diperoleh diolah dengan menggunakan sidik ragam sesuai dengan Rancangan Acak Lengkap (RAL) menurut (Hading, 2014). Apabila berpengaruh nyata akan dilakukan uji lanjut Duncan dengan bantuan program SPSS versi 16.0.

Model matematikanya adalah: $Y \mathrm{ij}=\mu+\tau \mathrm{i}+€ \mathrm{ij}$

Keterangan:

Yij $\quad=$ Nilai Pengamatan dengan ulangan ke-j

$\mu \quad=$ Rata - rata umum (nilai tengah pengamatan)

ti $\quad=$ Pengaruh Perlakuan ke- i i $=1,2,3,4,5,6)$

$€ \mathrm{ij} \quad=$ Galat percobaan dari perlakuan ke-i pada pengamatan $\mathrm{ke}-\mathrm{j}(\mathrm{j}=1,2,3,4)$. 


\section{Hasil Penelitian}

\section{Lemak Kasar}

Rata-rata kandungan Lemak kasar silase kombinasi bahan jerami padi dan daun lamtoro sebagai pakan ternak ruminansia, selengkapnya dapat dilihat pada gambar 1 .

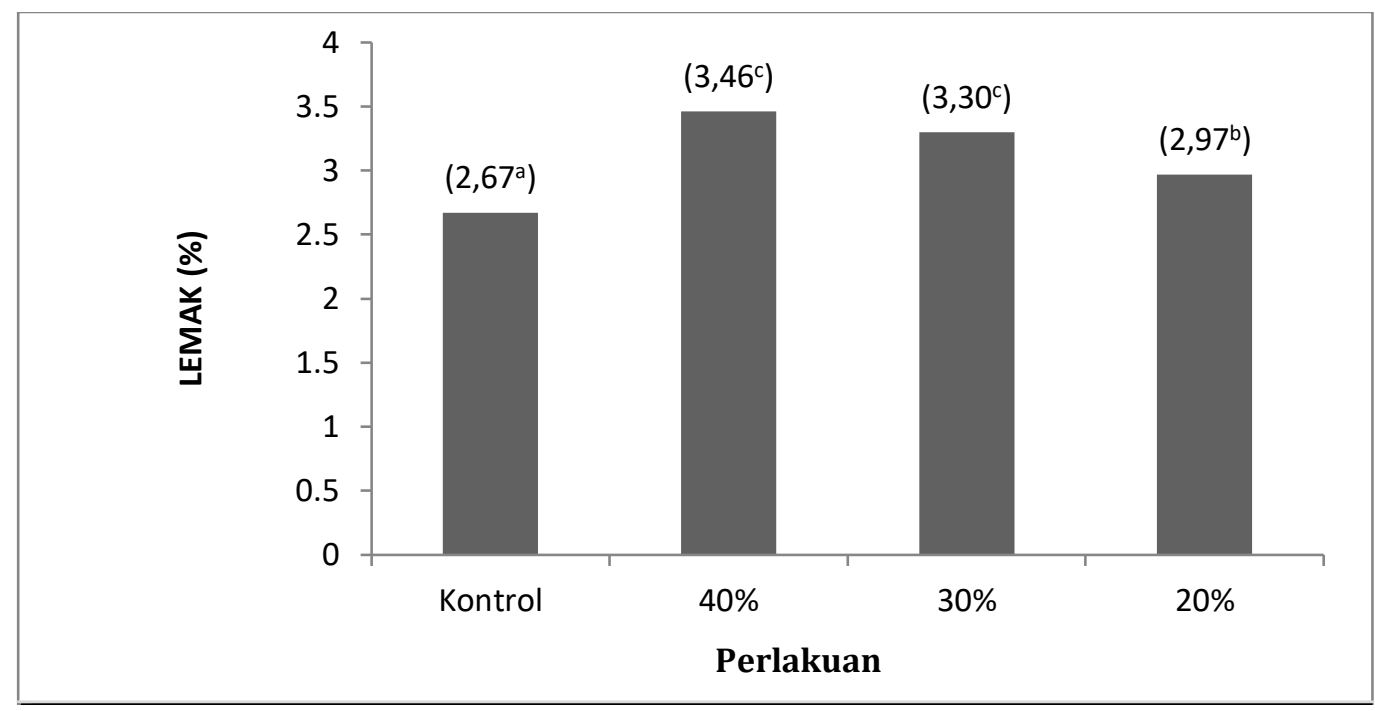

\section{Gambar 1. Rata-Rata Kandungan Lemak Kasar Silase Kombinasi Jerami Padi dan Daun Lamtoro sebagai Bahan Pakan Ternak Ruminansia}

Hasil analisis ragam menunjukkan bahwa kandungan lemak kasar silase kombinasi bahan jerami padi dan daun lamtoro sebagai bahan pakan dengan level yang berbeda berpengaruh sangat nyata $(\mathrm{P}<0,01)$. Hal ini dapat dilihat pada gambar 1 dimana kontrol berbeda nyata dengan $40 \%$, $30 \%$ dan $20 \%$, pada perlakuan $40 \%$ tidak berbeda nyata dengan $30 \%$ tapi berbeda nyata dengan $20 \%$ dan kontrol, begitu juga dengan $20 \%$ berbeda nyata dengan kontrol, $40 \%$ dan $30 \%$.

\section{Bahan Ekstrak Tanpa Nitrogen}

Rata-rata kandungan BETN silase kombinasi bahan jerami padi dan daun lamtoro sebagai pakan ternak ruminansia, selengkapnya dapat dilihat pada gambar 2.

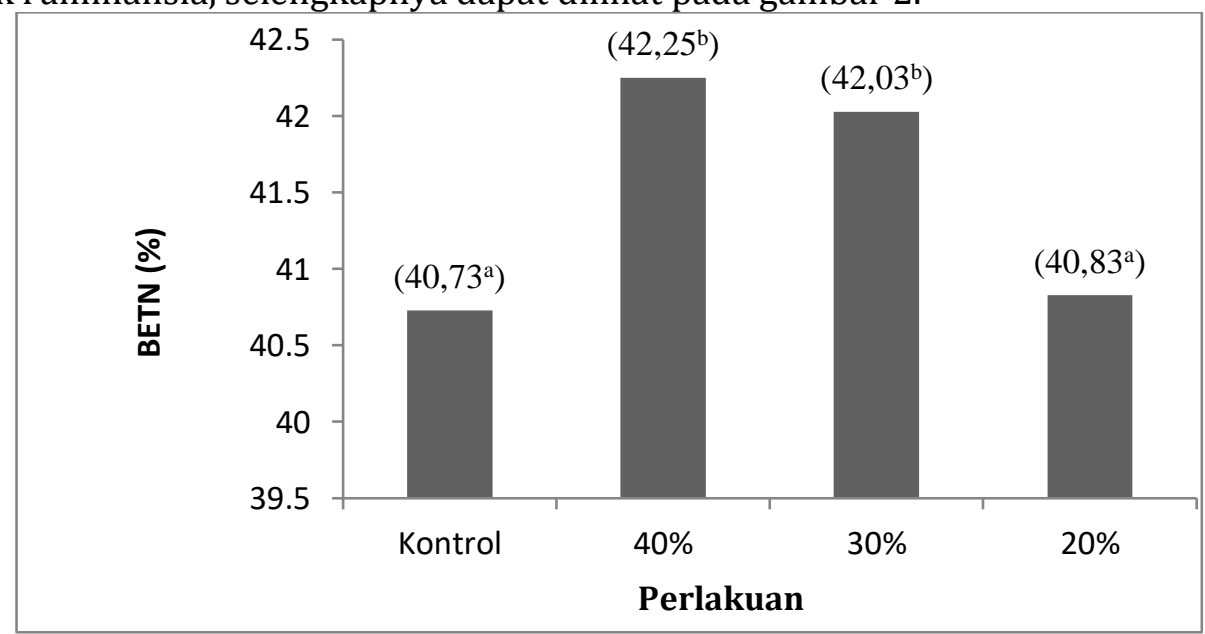

\section{Gambar 2. Rata-Rata Kandungan BETN Silase Kombinasi Jerami Padi dan Daun Lamtoro sebagai Bahan Pakan Ternak Ruminansia}


(hlm. 112-118)

Hasil analisis ragam menunjukkan bahwa kandungan BETN pada silase kombinasi bahan jerami padi dan daun lamtoro sebagai bahan pakan dengan level yang berbeda berpengaruh nyata $(\mathrm{P}<0.05)$. hal ini dapat dilihat pada gambar 2 dimana Kontrol berbeda nyata dengan $40 \%$ dan 30\% tapi tidak berbeda nyata dengan $20 \%$, begitu juga sebaliknya dimana $40 \%$ berbeda nyata dengan Kontrol dan $20 \%$ tetapi tidak berbeda nyata dengan $30 \%$.

\section{Pembahasan}

\section{Kandungan Lemak Kasar}

Berdasarkan hasil sidik ragam silase kombinasi jerami padi dan daun lamtoro menunjukkan bahwa terdapat pengaruh yang sangat nyata $(\mathrm{P}<0,01)$ terhadap kandungan lemak kasar pada pakan berbahan jerami padi dan daun lamtoro. Kandungan lemak kasar mengalami peningkatan tertinggi terdapat pada perlakuan $40 \%(3,46 \%)$ dan kandungan lemak kasar yang terendah terdapat pada perlakuan Kontrol (2,67\%). Hal tersebut menunjukkan bahwa kandungan lemak kasar mengalami peningkatan. Menurut Halili (2014) selama proses fermentasi mikroba yang ada pada bahan pakan berkembang biak, mikroba selulolitik akan menghasilkan ensim selulase yang mampu merombak ikatan lignosellulosa dan lignohemisellulosa yang terdapat pada batang jerami padi sehingga pada fermentasi menghasilkan kandungan nutrisi bahan pakan yang baik. Menurut Budiman (2014) peningkatan kadar lemak selama fermentasi disebabkan kandungan lemak kasar yang berasal dari masa sel mikroba yang tumbuh dan berkembang biak pada media selama fermentasi.

Meningkatnya kandungan lemak kasar pada kombinasi jerami padi dan daun lamtoro yang difermentasi mengindikasikan adanya sintesis asam lemak di dalam daun lamtoro tersebut. Hasil penguraian karbohidrat dalam proses fermentasi dapat menghasilkan asam-asam lemak. Sehingga kadar lemak dalam bahan yang difermentasi dapat meningkat. Hal ini sesuai dengan pendapat Budiman (2014) yang menyatakan bahwa fermentasi dapat diartikan sebagai pemecah gula menjadi alkohol, asam-asam organik dan $\mathrm{CO}$ oleh bakteri dalam kondisi anaerob.

Peningkatan kadar lemak kasar yang dihasilkan menunjukkan bahwa penambahan daun lamtoro dapat mempangaruhi kandungan lemak pada bahan pakan. Hal ini disebabkan karena komposisi semua bahan pakan mengandung lemak yang tinggi. Daun lamtoro juga merupakan hijauan yang memiliki lemak yang tinggi. Kandungan lemak daun lamtoro yaitu 5,4 (Indayani, 2012).

\section{Kandungan Bahan Ekstrak Tanpa Nitrogen (BETN)}

Berdasarkan hasil yang diperoleh menunjukkan bahwa perlakuan silase kombinasi jerami padi dan daun lamtoro berpengaruh nyata $(\mathrm{P}<0,05)$ terhadap kandungan BETN. Kandungan BETN tertinggi terdapat pada perlakuan $40 \%(42,25 \%)$ dan kandungan BETN yang terendah terdapat pada perlakuan Kontrol (40,73\%). Hal tersebut menunjukkan bahwa kandungan BETN yang tinggi terdapat pada silase dengan perlakuan penambahan persentase daun lamtoro yang lebih banyak.

Rataan kandungan BETN pada silase kombinasi jerami padi dan daun lamtoro mengalami peningkatan. Hal tersebut menunjukkan bahwa semakin banyak penambahan daun lamtoro maka semakin tinggi kandungan BETN. Hal ini sesuai pendapat Budiman (2014), bahwa BETN merupakan karbohidrat yang mudah dicerna yang terdapat dalam suatu bahan pakan, semakin tinggi BETN suatu bahan pakan semakin baik bahan tersebut dijadikan pakan. Bagi ternak ruminansia BETN yang tinggi dapat menyediakan karbohidrat yang mudah larut dan dengan cepat digunakan oleh mikroba rumen untuk membentuk rangka carbon (C).

Berdasarkan hasil bahwa meningkatnya kandungan BETN diduga disebabkan karna sumbangan bahan pakan yang digunakan dalam membuat silase memiliki kandungan konsetrat yang tinggi, seperti yang diketahui bahwa konsentrat memiliki kandungan BETN yang tinggi dan mudah dicerna oleh ternak hal ini menjadi salah satu faktor meningkatnya kandungan BETN. Sesuai dengan pendapat (Kurniati, 2016) yang menyatakan bahwa konsentrat adalah pakan ternak 
yang mengandung serat kasar rendah energi dan BETN yang tinggi serta mudah dicerna oleh ternak.

Terjadi peningkatan BETN tersebut kemungkinan juga disebabkan karena dalam proses fermentasi jumlah bakteri semakin meningkat sehingga mendegradasi senyawa komplek menjadi senyawa yang lebih sederhana, dapat dilihat dengan menurunnya kandungan serat kasar pada silase pakan berbahan jerami padi dan daun lamtoro. Menurut Gazali (2014) menyatakan bahwa fermentasi yaitu proses perombakan dari struktur keras secara fisik, kimia dan biologi sehingga bahan dari struktur yang komplek menjadi sederhana, maka daya cerna ternak menjadi lebih efisien. Didukung oleh Hasni (2009) menyatakan bahwa penurunan kandungan serat kasar dari suatu bahan pakan akan meningkatkan kandungan BETNnya.

Seperti dikemukakan oleh Sanchez (2009) bahwa turunnya kandungan serat kasar akibat aktivitas mikroba mengakibatkan meningkatnya kandungan BETN, dengan semakin banyak gula sederhana yang dihasilkan. Bahan ekstrak tanpa nitrogen ditentukan melalui pengurangan bahan kering dengan seluruh komponen nutrien substrat. Nilai BETN sangat bergantung pada kandungan nutrien lain. Kandungan BETN mengalami peningkatan selama proses fermentasi. Peningkatan kandungan BETN dapat terjadi karena perombakan karbohidrat struktural, hemiselulosa menjadi bahan mudah larut. Sesuai pendapat Budiman (2014) bahwa hemiselulosa dirombak menjadi monomer gula dan asam asetat.

\section{Kesimpulan}

Berdasarkan hasil dan pembahasan penelitian, maka dapat disimpulkan bahwa pakan dengan kombinasi jerami padi dan daun lamtoro mempengaruhi kandungan lemak kasar dan BETN. Dimana perlakuan 40\% dengan kombinasi bahan jerami padi $60 \%$ dan daun lamtoro $40 \%$ menunjukkan hasil yang terbaik untuk kandungan lemak dan BETN.

\section{Referensi}

Budiman, R. M. (2014). Analisis Kandungan Bahan Ekstrat Tanpa Nitrogen (BETN) dan Lemak Kasar Pada Rumput Taiwan (Pennisetum purpereum) dan Kulit Buah Pisang Kepok Yang Difermentasi Dengan Trichoderma sp., Jurusan Peternakan, Fakultas Pertanian, Peternakan dan Perikanan, UMPAR. Parepare.

Gazali, M. (2014). Kandungan Lemak Kasar, Serat Kasar dan BETN Pakan Berbahan Jerami Padi, Daun Gamal dan Urea Mineral Molases Liquid dengan Perlakuan Berbeda, Jurusan Nutrisi dan Makanan Ternak, Fakultas Peternakan, UNHAS. Makassar.

Hading, R. A. (2014). Kandungan Protein Kasar, Lemak Kasar, Serat Kasar dan BETN Silase Pakan Lengkap Berbahan Dasar Rumput Gajah dan Biomassa Murbei. Jurusan Nutrisi dan Makanan Ternak, Fakultas Peternakan, UNHAS. Makassar.

Halili, A. (2014). Analisis Kandungan Selulosa, Hemiselulosa, Lignin, dan Silica Ransum Lengkap Berbahan Jerami Padi (Oryzas sativa), Daun Gamal, dan Umml, Jurusan Nutrisi dan Makanan Ternak, Fakultas Peternakan, UNHAS. Makassar.

Hartadi, H., S. Reksohadiprojo, \& A.D. Tillman. (2005). Tabel Komposisi Pakan untuk Indonesia. Gadjah Mada University Press. Yogyakarta. 
Evaluasi Kandungan Lemak Kasar dan BETN Silase Daun Lamtoro pada Level yang Berbeda Sebagai Bahan Pakan Utama Pakan Komplit

(hlm. 112-118)

Hartanto. (2008). Pengaruh Penggantian Konsentrat dengan Daun Lamtoro Kering (Leucaena leucocephala) Dalam Ransum Terhadap Performan Kambing Kacang Jantan, Jurusan Peternakan, Fakuktas Pertanian, Universitas Sebelas Maret. Surakarta.

Hasni. (2009). Kandungan Protein Kasar dan Serat Kasar Silase dari Rumput Gajah (Pennisetum purpureum, Schumacher \& Thonn) yang Diberi Pupuk Organik pada Berbagai Umur Pemotongan. Skripsi Sarjana.Fakultas Peternakan Universitas Hasanuddin. Makassar.

Indah, S.A. (2016). Kandungan Protein Kasar dan Serat Kasar Silase Pakan Lengkap Berbahan Utama Batang Pisang (Musa paradisiaca) Dengan Lama Inkubasi Yang Berbeda, Jurusan Nutrisi dan Makanan Ternak, Fakultas Peternakan, UNHAS. Makassar.

Indayani, D. (2012). Nilai Gizi Daun Lamtoro (Leucaena leucepala) dan Pemanfatannya Sebagai Pakan Ternak Ruminansia, Jurusan Nutrisi dan Makanan Ternak, Fakultas Peternakan, UNHAS. Makassar.

Kurniati. (2016). Kandungan Lemak Kasar, Bahan Organik, Dan BETN Silase Pakan Lengkap Berbahan Utama Batang Pisang Dengan Lama Inkubasi yang Berbeda, Fakultas Peternakan, UNHAS. Makassar.

Prabowo, H. (2006). Pengaruh Imbangan Rumput Lapangan dengan Daun Lamtoro (Leucaena glauca) terhadap Performan Domba Lokal Jantan. Skripsi S1 Fakultas Pertanian. Universitas Sebelas Maret. Surakarta.

Sanchez. C. (2009). Lignocellulosic residues: biodegration and bioconversion by fungi. Biotechnol. Advan, (27), 185-19.

\begin{tabular}{|l|l|}
\hline Juwandi & $\begin{array}{l}\text { Program Studi Peternakan, Fakultas Pertanian, Peternakan dan Perikanan } \\
\text { Universitas Muhammadiyah Parepare } \\
\text { E-mail: juwandi014@gmail.com }\end{array}$ \\
\hline Munir & $\begin{array}{l}\text { Program Studi Peternakan, Fakultas Pertanian, Peternakan dan Perikanan } \\
\text { Universitas Muhammadiyah Parepare } \\
\text { E-mail: } \text { munire umpar@yahoo.co.id }\end{array}$ \\
\hline Fitriani & $\begin{array}{l}\text { Program Studi Peternakan, Fakultas Pertanian, Peternakan dan Perikanan } \\
\text { Universitas Muhammadiyah Parepare } \\
\text { E-mail: fitrianisahidin@gmail.com }\end{array}$ \\
\hline
\end{tabular}

